\title{
A detailed view on 1,8-cineol biosynthesis by Streptomyces clavuligerus
}

\author{
Jan Rinkel, Patrick Rabe, Laura zur Horst and Jeroen S. Dickschat ${ }^{*}$
}

\author{
Full Research Paper \\ Address: \\ Kekulé-Institute of Organic Chemistry and Biochemistry, University of \\ Bonn, Gerhard-Domagk-Straße 1, 53121 Bonn, Germany \\ Email: \\ Jeroen S. Dickschat* - dickschat@uni-bonn.de \\ * Corresponding author \\ Keywords: \\ biosynthesis; enzyme mechanisms; isotopic labelling; \\ stereochemistry; terpenes
}

Beilstein J. Org. Chem. 2016, 12, 2317-2324.

doi:10.3762/bjoc. 12.225

Received: 18 August 2016

Accepted: 28 October 2016

Published: 04 November 2016

This article is part of the Thematic Series "Chemical biology".

Guest Editor: H. B. Bode

(c) 2016 Rinkel et al.; licensee Beilstein-Institut.

License and terms: see end of document.

\begin{abstract}
The stereochemical course of the cyclisation reaction catalysed by the bacterial 1,8-cineol synthase from Streptomyces clavuligerus was investigated using stereospecifically deuterated substrates. In contrast to the well investigated plant enzyme from Salvia officinalis, the reaction proceeds via $(S)$-linalyl diphosphate and the $(S)$-terpinyl cation, while the final cyclisation reaction is in both cases a syn addition, as could be shown by incubation of $\left(2-{ }^{13} \mathrm{C}\right)$ geranyl diphosphate in deuterium oxide.
\end{abstract}

\section{Introduction}

Among all classes of natural products the climax of structural diversity and complexity is reached within the largest, the terpenoids. An estimated number of 75,000 different compounds are known from all kinds of organisms including plants [1], bacteria [2-5], fungi [6] and, as recently shown, even social amoebae [7]. These molecules are all made from only a handful of linear and achiral precursors such as geranyl diphosphate (GPP, monoterpenes), farnesyl diphosphate (FPP, sesquiterpenes) and geranylgeranyl diphosphate (GGPP, diterpenes). Terpene cyclases (type I) contain a trinuclear $\left(\mathrm{Mg}^{2+}\right)_{3}$ cluster in their active site that is stabilised by binding to several highly conserved motifs including the aspartate-rich motif (DDXXD) and the NSE triad $(\mathrm{ND}(\mathrm{L}, \mathrm{I}, \mathrm{V}) \mathrm{XSXXXE}$, modified in plants to a DTE triad: DD(L,I,V)XTXXXE) [8]. Their substrates bind with the diphosphate portion to the $\left(\mathrm{Mg}^{2+}\right)_{3}$ cluster and via hydrogen bridges to a highly conserved arginine (diphosphate sensor) and a RY dimer [9]. The substrate is ionised by diphosphate abstraction and the resulting allyl cation undergoes a domino reaction via a series of cationic intermediates and a final deprotonation or attack of water to yield a terpene hydrocarbon or alcohol. This reaction cascade proceeds in a hydrophobic cavity from which water is excluded to enable carbocation chemistry in an aqueous environment. Furthermore, the hydrophobic cavity provides a template that arranges the substrate in a certain conformation to determine the formation of a specific product. Single residues such as phenylalanines are involved in the stabilisation of cationic intermediates, e.g., by cation $-\pi$ interactions [8-10]. The overall process usually generates an en- 
antiomerically pure (poly)cyclic terpene with several stereogenic centres. A large variety of carbon skeletons is accessible, e g., more than 120 skeletons each representing various stereoisomers and constitutional isomers with different positioning of olefinic double bonds or alcohol functions are known just for sesquiterpenes [11]. The structural diversity of terpenoids can be further increased by the action of tailoring enzymes such as cytochrome P450 monooxygenases and acyl transferases $[12,13]$. Very few cases are known in which terpene cyclases generate an achiral product as exemplified by the monoterpene 1,8-cineol (eucalyptol, 1) and the sesquiterpenes germacrene B (2) and $\alpha$-humulene (3) (Figure 1).

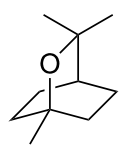

1

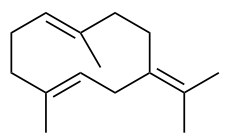

2

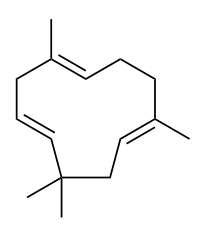

3
Figure 1: Selection of achiral terpenes.

A direct 1,6-cyclisation of the monoterpene precursor GPP to 1 is prevented by the topological constraints associated with the (2E) geometry which necessitates the isomerisation of GPP (4) to linalyl diphosphate $(\mathrm{LPP}, \mathbf{5})$ followed by an anti,endo- $\mathrm{S}_{\mathrm{N}}$ 'cyclisation [14], but the stereochemical course of this reaction is not readily clear and may proceed via either enantiomer of the $\alpha$-terpinyl cation (6, Scheme 1). Isotopic labelling experiments currently experience a revival [15] and are a very powerful method to follow the enzyme mechanisms of terpene cyclases [16-24] including the stereochemical courses of the cyclisation reactions (reviewed in [25]). While the stereochemical course of the GPP cyclisation to 1 has been investigated for the 1,8-cineol synthase from Salvia officinalis [26,27], it is unknown for the bacterial enzyme that was recently reported from Streptomyces clavuligerus [28]. Here we describe isotopic labelling experiments that gave insights into the cyclisation mechanism of the bacterial 1,8-cineol synthase.

\section{Results}

\section{The absolute configuration of the inter- mediate terpinyl cation}

While the two possible cyclisation pathways via $(R)$ - and $(S)-6$ to 1 cannot be distinguished with unlabelled GPP, its two enantiotopic protons at $\mathrm{C}-1$ (indicated by $\mathrm{H}_{R}$ for the pro- $R$ hydrogen and $\mathrm{H}_{S}$ for the pro-S hydrogen) end up in diastereotopic positions of 1 . Thus, a labelling experiment using the deuterated substrates $(R)-\left(1-{ }^{2} \mathrm{H}\right) \mathrm{GPP}\left(\mathrm{H}_{R}={ }^{2} \mathrm{H}, \mathrm{H}_{S}=\mathrm{H}\right)$ and $(S)-\left(1-{ }^{2} \mathrm{H}\right) \mathrm{GPP}\left(\mathrm{H}_{R}=\mathrm{H}, \mathrm{H}_{S}={ }^{2} \mathrm{H}\right)$ can give insights whether the cyclisation proceeds via $(R)$ - or $(S)-\mathbf{6}$, by determination in which of the distinguishable diastereotopic positions the label ends up. The synthesis of the two enantiomers of $\left(1-{ }^{2} \mathrm{H}\right) \mathrm{GPP}$ (Scheme S1, Supporting Information File 1) was performed by

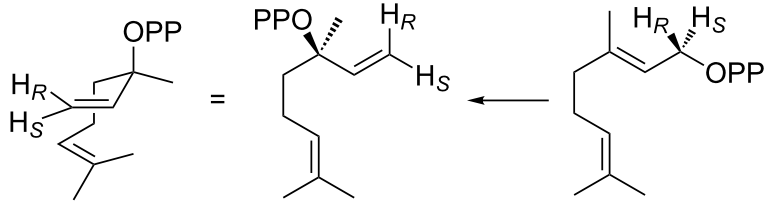

$(R)-5$<smiles>CC1=C[C@H](C)[C@H](C(C)C)CC1</smiles>
$\mathrm{H}_{2} \mathrm{O}$

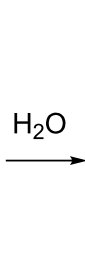<smiles></smiles><smiles>C1CCCCC1</smiles>

$(R)-6$
$(R)-7$<smiles>[1H][C@@]1(C)CC(C)CCC1C(C)(C)O</smiles><smiles>[1H][C@@H]([Po])C=C(C)CCC=C(C)C</smiles>

4<smiles>[R][C@]1(C)C[C@H](C)CC[C@H]1C(C)(C)O</smiles>

8<smiles>[PH3+][TeH]</smiles><smiles>[R]C1CC2(C)OC1(C)CC2C</smiles>

1
8<smiles>I[IH+]</smiles><smiles>CC=CC(C)(CCC=C(C)C)OP</smiles>

(S)-5<smiles>[R9][C@]1(C)C=C(C)CC[C@H]1C(C)(C)O</smiles>

$\mathrm{H}_{2} \mathrm{O}$<smiles>[R][C@]1(C)C=C(C)CC[C@H]1C(C)C</smiles>

(S)-7

Scheme 1: Cyclisation of GPP to 1 via the $(R)$-terpinyl cation $((R)-6$, left) or the $(S)$-terpinyl cation $((S)-6$, right). 
Alpine borane reduction [29] (both enantiomers of this reagent are commercially available) of $\left(1-{ }^{2} \mathrm{H}\right)$ geranial to $(R)$ - and $(S)-\left(1-{ }^{2} \mathrm{H}\right)$ geraniol that were obtained with high enantiomeric excess ( $>95 \%$ ee) as determined by Mosher ester analysis (Figure S1, Supporting Information File 1). The alcohols were subsequently converted into the corresponding diphosphates using triethylammonium phosphate in trichloroacetonitrile [30,31]. The gene encoding the 1,8-cineol synthase [28] was cloned into the yeast-to-Escherichia coli shuttle vector pYE-
Express by homologous recombination in yeast [32], followed by expression in E. coli BL21. The protein was purified by $\mathrm{Ni}^{2+}$-NTA affinity chromatography and used to convert both $(R)$ - and $(S)-\left(1-{ }^{2} \mathrm{H}\right)$ GPP into $\left({ }^{2} \mathrm{H}\right)-1$ (in agreement with the findings described in reference [28], $\mathbf{1}$ is the only product from unlabelled GPP as was shown by GC-MS, Figure S2, Supporting Information File 1). The obtained products were analysed by HSQC spectroscopy (Figure 2). While for unlabelled 1 a 2:2 signal intensity is observed for the crosspeaks representing the

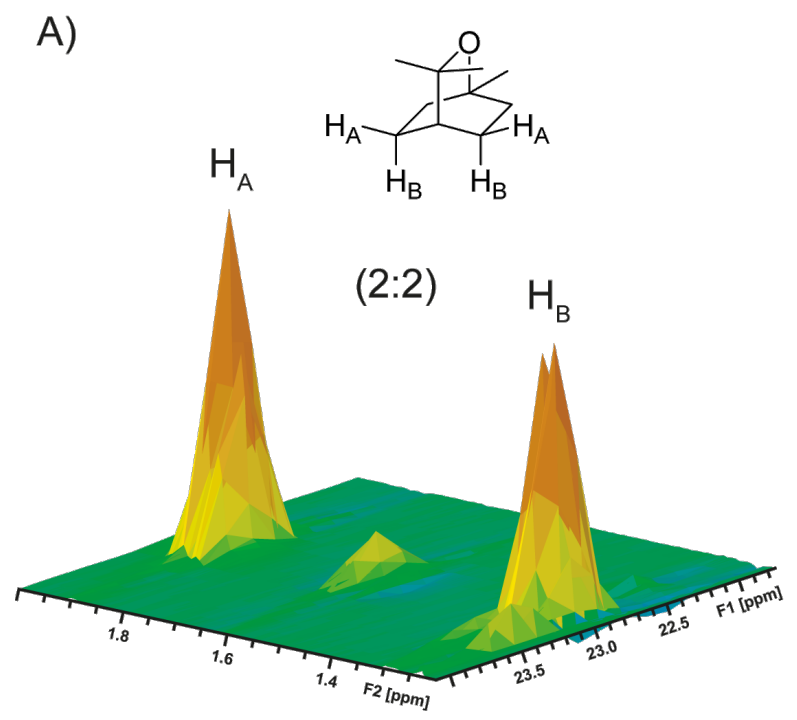

$\mathrm{H}_{\mathrm{A}}: \delta=1.95-1.84 \mathrm{ppm}$
$\mathrm{H}_{\mathrm{B}}: \delta=1.33-1.24 \mathrm{ppm}$

C-3/C-5: $\delta=23.3 \mathrm{ppm}$
B)
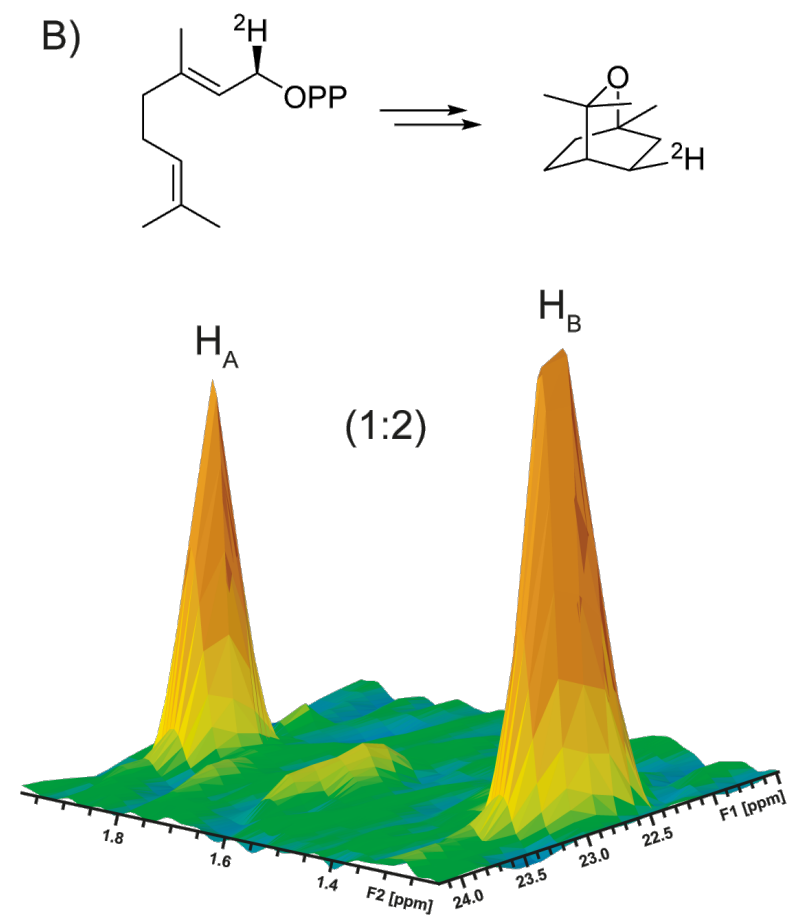

C)
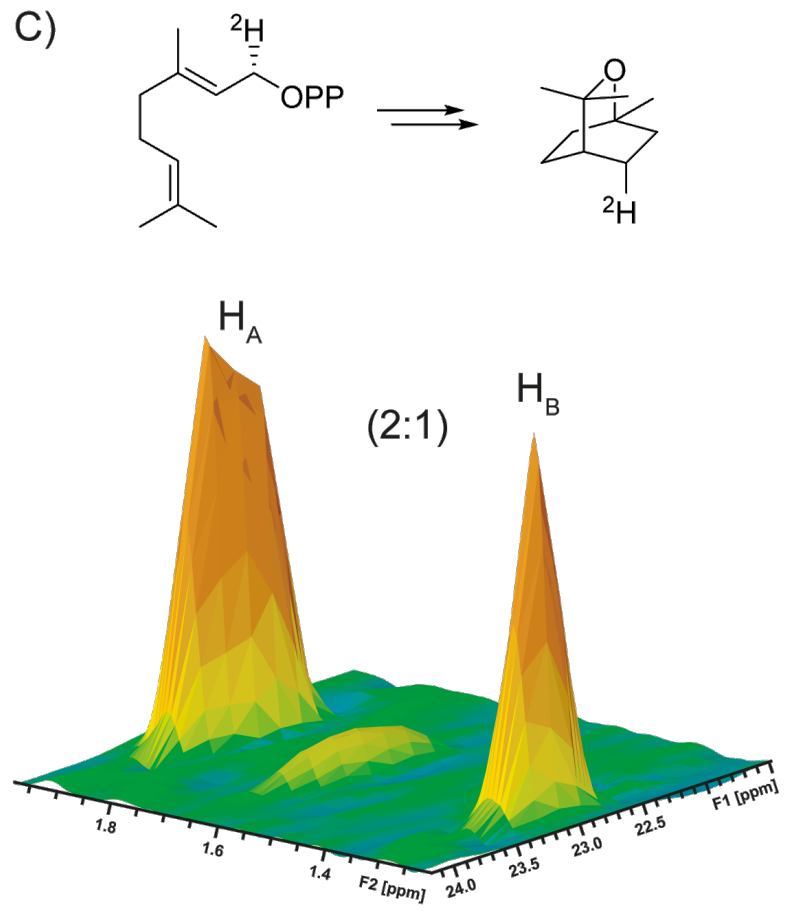

Figure 2: Partial HSQC spectra showing the region of crosspeaks for $\mathrm{H}_{A}$ and $\mathrm{H}_{B}$ connected to $\mathrm{C}-3$ and $\mathrm{C}-5$ of $\left.\mathrm{A}\right)$ unlabelled 1, B) ( $\left.{ }^{2} \mathrm{H}\right)-1$ obtained by enzymatic conversion of $(R)-\left(1-{ }^{2} \mathrm{H}\right) \mathrm{GPP}$, and C) $\left({ }^{2} \mathrm{H}\right)-1$ obtained by enzymatic conversion of $(S)-\left(1-{ }^{2} \mathrm{H}\right) \mathrm{GPP}$. The indicated chemical shift data are for unlabelled 1 (for full data cf. Table S1, Supporting Information File 1). 
two pairs of enantiotopic hydrogens $\mathrm{H}_{\mathrm{A}}$ and $\mathrm{H}_{\mathrm{B}}$ connected to carbons $\mathrm{C}-3$ and $\mathrm{C}-5$, the sample obtained from $(R)-\left(1-{ }^{2} \mathrm{H}\right) \mathrm{GPP}$ gave a 1:2 ratio of signal intensities (i.e., $\mathrm{H}_{\mathrm{A}}={ }^{2} \mathrm{H}$ ), while the sample from $(S)-\left(1-{ }^{2} \mathrm{H}\right) \mathrm{GPP}$ resulted in ratio of $2: 1$ by peak integration (i.e., $\mathrm{H}_{\mathrm{B}}={ }^{2} \mathrm{H}$ ), indicating the cyclisation via $(S)$-LPP $((S)-5)$ and the $(S)$-terpinyl cation $((S)-6)$ (Scheme 1, right).

\section{Syn versus anti addition in the final ring closure}

The final cyclisation step from (S)-7 via $\mathbf{8}$ to $\mathbf{1}$ can in principle proceed either via a $s y n$ or an anti addition to the olefinic double bond, requiring a protonation of the original C-2 of GPP. To distinguish between these alternatives $\left(2-{ }^{13} \mathrm{C}\right) \mathrm{GPP}$ was synthesised from sulcatone (Scheme S2, Supporting Information File 1) and converted by the 1,8-cineol synthase in deuterium oxide. The obtained product was analysed by HSQC spectroscopy (Figure 3A), showing that deuterium is taken up into the exo position at the ${ }^{13} \mathrm{C}$-labelled $\mathrm{C}-2$ of $\mathbf{1}$ (indicated by $\mathrm{H}^{\prime}$ ), while the endo position ( $\mathrm{H}^{\prime \prime}$ ) is occupied by the proton from the substrate, resulting in a strong crosspeak [22]. Furthermore, deuterium incorporation at C-2 was indicated by a strongly enhanced triplet in the ${ }^{13} \mathrm{C}$ NMR spectrum due to ${ }^{13} \mathrm{C}-{ }^{2} \mathrm{H}$-spin coupling (Figure S4, Supporting Information File 1) [11,20,23]. This finding is in agreement with a syn addition to the olefinic double bond of $(S)-7$ in the final cyclisation step. It is possible that the proton is directly transfered from the protonated hydroxy function in $(S)-7$ to C-2 (Figure 3B). Alternatively, a deprotonation of $(S)-7$ to the hypothetical neutral intermediate $\alpha$-terpineol followed by reprotonation at C-2 from the $S i$ face can be assumed, but these two alternatives cannot be distinguished based on the labelling experiments described here.

\section{Discussion}

Plant and bacterial terpene cyclases show important structural differences [33]. While plant monoterpene synthases are

A)
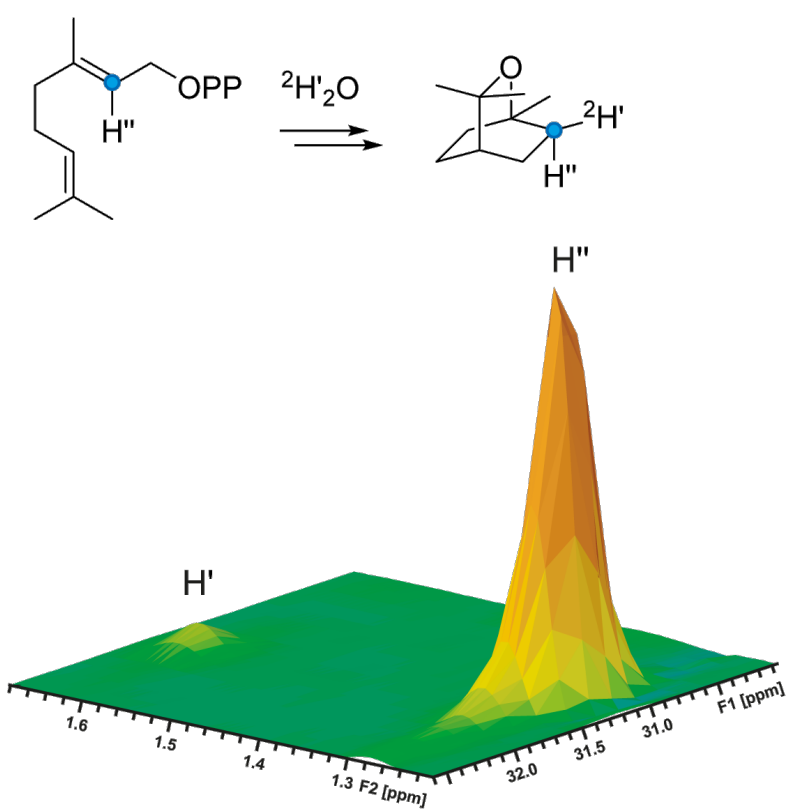

$\mathrm{H}^{\prime}: \delta=1.67-1.56 \mathrm{ppm}$

$\mathrm{H}^{\prime \prime}: \delta=1.33-1.24 \mathrm{ppm}$

C-2/C-6: $\delta=31.9 \mathrm{ppm}$

B)

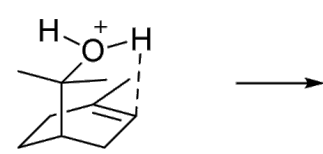

(S)-7

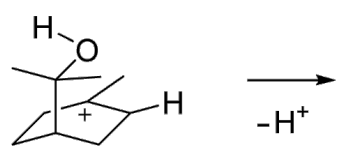

8

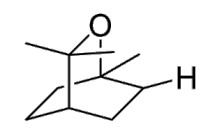

1

Figure 3: A) Partial HSQC spectrum showing the region of crosspeaks of C-2 with its directly connected hydrogens $H^{\prime}$ and $H^{\prime \prime}$ for compound $\left(2-{ }^{13} \mathrm{C}, 2-{ }^{2} \mathrm{H}\right)-1$ obtained by enzymatic conversion of $\left(2-{ }^{13} \mathrm{C}\right) \mathrm{GPP}$ in deuterium oxide. Deuterium was specifically incorporated into $\mathrm{H}^{\prime}$ position. The indicated chemical shift data are for unlabelled 1 (for full data cf. Table S1, Supporting Information File 1). Blue circles point to ${ }^{13} \mathrm{C}$-labelled carbons. B) Intramolecular proton transfer from the protonated hydroxy function in (S)-7 to C-2. 
composed of $\alpha$ and $\beta$ domains and exhibit a quarternary $\alpha_{2} \beta_{2}$ structure [34,35], bacterial mono- and sesquiterpene cyclases are monodomain enzymes $(\alpha)[9,10,36]$. Accordingly, also the 1,8-cineol synthases from Salvia officinalis and from Streptomyces clavuligerus are not related and have evolved independently. While the plant enzyme was shown to convert GPP via $(R)$-LPP $((R)-5)$ and the $(R)$-terpinyl cation $((R)-6)$ into 1 [27], the experiments described here revealed a different course for the bacterial enzyme via $(S)$-6. This finding is particularly interesting, because it reflects the frequent observation that the (chiral) products of bacterial terpene cyclases represent the opposite enantiomers as usually generated by plant enzymes $[24,37,38]$. Both enzymes from Salvia officinalis and from Streptomyces clavuligerus share the syn addition in the final cyclisation step which can be rationalised by a direct intramolecular proton transfer, circumventing the need of a low-energy neutral intermediate such as $\alpha$-terpineol. However, in case of the sesquiterpene ethers corvol ethers A (19) and B (18) a reprotonation step was shown to proceed from the opposite face than the preceeding attack of water, thus excluding a direct proton transfer from oxygen to the neighbouring carbon (reactions from 12 to 14 in Scheme 2). Conclusively, reprotonation of the neutral intermediate $\mathbf{1 3}$ is possible in this case [21].

\section{Experimental Cloning and homologous recombination}

Cells of Streptomyces clavuligerus ATCC 27064 were obtained from the Deutsche Sammlung von Mikroorganismen und Zellkulturen (DSMZ, Braunschweig, Germany). Cultivation was done in liquid 65 Gym medium (4 g yeast extract, $4 \mathrm{~g}$ glucose, $10 \mathrm{~g}$ malt extract, $1 \mathrm{~L}$ water, $\mathrm{pH}$ 7.2) and isolation of genomic DNA was performed using a standard protocol. The gene WP_003952918 encoding the 1,8-cineol synthase was amplified using forward primer (ATGCCCGCCGGCCACGAAGA) and reversed primer (TCACCAAGGGGTGGTGGCCC). The isolated PCR product was elongated for homologous recombination with pYE-Express in yeast with a second set of primers (GGCAGCCATATGGCTAGCATGACTGGTGGAATGCCCGCCGGCCACGAAGA and TCTCAGTGGTGGTGGTGGTGGTGCTCGAGTTCACCAAGGGGTGGTGG CCC). This elongated product was transformed in Saccha-<smiles>CC(C)=CCCC(C)=CCCC(C)=CCOP</smiles>

9

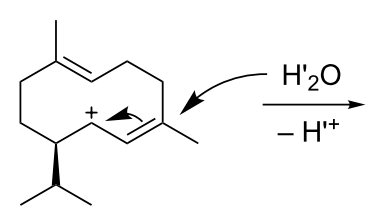

12<smiles>CC(C)C1CC[C@@H](C)[C@H]2CC[C@](C)(O)[C@H]12</smiles><smiles>C=CC(C)(CCC=C(C)CCC=C(C)C)PO</smiles>

10<smiles>CC1=CCC[C@](C)(O)/C=C\[C@H](C(C)C)CC1</smiles>

13

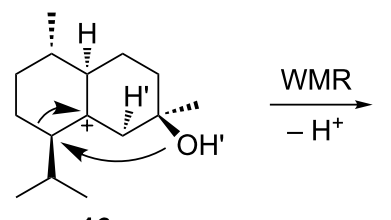

16

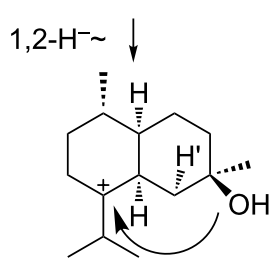

17<smiles>CCCCCCC</smiles><smiles>CCC=C(C)CCC(CC=C(C)C)C(C)C</smiles>
11<smiles>CC(C)C1CCC(C)[C@H]2CC[C@](C)(O)[C@H]12</smiles>

14<smiles>CC(C)C1O[C@@]2(C)CC[C@@H](C)[C@H]1CC2</smiles>

18

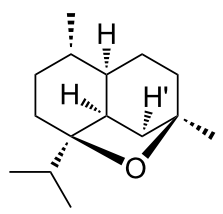

19 
romyces cerevisiae FY834 together with linearised vector pYEExpress [32] (EcoRI and HindIII digestion) using the LiOAc/SS carrier DNA protocol [39]. Transformed cells were plated on SM-URA medium (20 g glucose, $1.7 \mathrm{~g}$ yeast nitrogen base, $5 \mathrm{~g}$ ammonium sulphate, $0.77 \mathrm{~g}$ nutritional supplement minus uracil, $24 \mathrm{~g}$ agar, $1 \mathrm{~L}$ water) and grown for 3 days at $28{ }^{\circ} \mathrm{C}$. Plasmids were isolated using the kit Zymoprep Yeast Plasmid Miniprep II (Zymo Research, Irvine, USA), shuttled in E. coli BL21 by electroporation and confirmed by sequencing.

\section{Incubation experiments with $(1 R)$ - and (1S)-(1-2H)GPP}

A preculture of $E$. coli BL21 cells carrying the plasmid pYE_WP003952918 in 2YT medium (16 g trypton, $10 \mathrm{~g}$ yeast extract, $5 \mathrm{~g} \mathrm{NaCl}, 1 \mathrm{~L}$ water, $\mathrm{pH}$ 7.2) was grown overnight to inoculate a $2 \mathrm{YT}$ main culture $(2 \mathrm{~L})$. The cultures were shaken at $160 \mathrm{rpm}, 37^{\circ} \mathrm{C}$ until $\mathrm{OD}_{600}=0.4$ was reached. Prior to induction with IPTG $(0.4 \mathrm{mM})$, the cultures were cooled down to $18^{\circ} \mathrm{C}$. After incubation overnight $\left(160 \mathrm{rpm}, 18^{\circ} \mathrm{C}\right)$, cells were harvested by centrifugation $\left(5000 \mathrm{~g}, 4^{\circ} \mathrm{C}, 45 \mathrm{~min}\right)$ and resuspended in binding buffer $\left(20 \mathrm{~mL} ; 20 \mathrm{mM} \mathrm{Na}_{2} \mathrm{HPO}_{4}, 0.5 \mathrm{mM}\right.$ $\mathrm{NaCl}, 20 \mathrm{mM}$ imidazole, $1 \mathrm{mM} \mathrm{MgCl}{ }_{2}, \mathrm{pH}$ 7.0). The cells were crushed by ultra-sonification $\left(6 \times 1 \mathrm{~min}, 4{ }^{\circ} \mathrm{C}\right)$ and the cell debris pellet was separated by centrifugation $(10 \mathrm{~min}, 15500 \mathrm{~g}$, $\left.4{ }^{\circ} \mathrm{C}\right)$. The soluble fraction was loaded onto a $\mathrm{Ni}^{2+}$-NTA affinity column (Novagen) and treated with binding buffer $(2 \times 10 \mathrm{~mL})$. The target protein was then eluted with elution buffer $\left(2 \times 10 \mathrm{~mL} ; 20 \mathrm{mM} \mathrm{Na} 2 \mathrm{HPO}_{4}, 0.5 \mathrm{M} \mathrm{NaCl}, 0.5 \mathrm{M}\right.$ imidazole, $\left.1 \mathrm{mM} \mathrm{MgCl}_{2}, \mathrm{pH} 7.0\right)$ and used directly for incubations with $5 \mathrm{mg}$ of $(1 R)$ - and $(1 S)-\left(1-{ }^{2} \mathrm{H}\right) \mathrm{GPP}$, solved in incubation buffer ( $50 \mathrm{mM}$ Tris/ $\mathrm{HCl}, 10 \mathrm{mM} \mathrm{MgCl} 2,20 \% \mathrm{v} / \mathrm{v}$ glycerol, $\mathrm{pH} 8.2$ ) to reach a final substrate concentration of $0.2 \mathrm{mg} / \mathrm{mL}$. The enzyme reaction was incubated for $2 \mathrm{~h}$ at $28 \mathrm{~h}$, overlaid with $400 \mu \mathrm{L}\left({ }^{2} \mathrm{H}_{6}\right)$ benzene and further incubated overnight. The organic phase was separated, dried over $\mathrm{MgSO}_{4}$ and directly analysed by GC-MS and NMR.

\section{Incubation experiment with $\left(2-{ }^{13} \mathrm{C}\right) \mathrm{GPP}$}

Enzyme purification starting from an E. coli expression culture $(0.5 \mathrm{~L})$ was performed as described above. The last washing fraction was substituted with ${ }^{2} \mathrm{H}_{2} \mathrm{O}$-based binding buffer and elution was done with ${ }^{2} \mathrm{H}_{2} \mathrm{O}$-based elution buffer. The first elution fraction was incubated with $\left(2-{ }^{13} \mathrm{C}\right) \mathrm{GPP}(0.8 \mathrm{mg})$ for $16 \mathrm{~h}$ at $28{ }^{\circ} \mathrm{C}$. The enzyme reaction was extracted with $\left({ }^{2} \mathrm{H}_{6}\right)$ benzene $(0.6 \mathrm{~mL})$, dried with $\mathrm{MgSO}_{4}$ and the extract was analysed directly by GC-MS and NMR.

\section{NMR spectroscopy}

To record NMR spectra, instruments AV Avance DMX-500 (500 MHz), DPX-400 (400 MHz) and AV III HD Cryo $(700 \mathrm{MHz})$ from Bruker were used. Solvent signals were used to reference the spectra $\left({ }^{1} \mathrm{H}\right.$ NMR, residual proton signals: $\left({ }^{2} \mathrm{H}_{6}\right)$ benzene $\delta=7.16 ;{ }^{13} \mathrm{C}$ NMR: $\left({ }^{2} \mathrm{H}_{6}\right)$ benzene $\left.\delta=128.06\right)$ [40].

\section{GC-MS analysis}

An Agilent 7890B gas chromatograph equipped with a HP5-MS silica column ( $30 \mathrm{~m}, 0.25 \mathrm{~mm}$ inner diameter, $0.50 \mu \mathrm{m}$ film) connected to an Agilent 5977A inert mass selective detector was used to acquire GC-MS data. Instrumental settings were: (1) inlet pressure: $77.1 \mathrm{kPa}, \mathrm{He}: 23.3 \mathrm{~mL} / \mathrm{min},(2)$ transfer line: $250{ }^{\circ} \mathrm{C}$, (3) electron energy: $70 \mathrm{eV}$. The $\mathrm{GC}$ was set to $50{ }^{\circ} \mathrm{C}$ starting temperature for $5 \mathrm{~min}$, then increasing with $5{ }^{\circ} \mathrm{C}$ per minute to $320^{\circ} \mathrm{C}$ and holding this temperature for another $5 \mathrm{~min}$. The injection volume was $2 \mu \mathrm{L}$ and the inlet was operating in split mode (10:1, $60 \mathrm{~s}$ valve time). Helium was used as the carrier gas at $1 \mathrm{~mL} / \mathrm{min}$. Retention indices were determined against a homologous series of $n$-alkanes $\left(\mathrm{C}_{8}-\mathrm{C}_{40}\right)$.

\section{Synthesis of $\left(2-{ }^{13} \mathrm{C}\right)$ geranyl diphosphate}

$\left(2-{ }^{13} \mathrm{C}\right)$ Geraniol was synthesised as reported previously [41]. The synthetic $\left(2-{ }^{13} \mathrm{C}\right)$ geraniol $(16 \mathrm{mg}, 0.072 \mathrm{mmol}, 1.0$ equiv) was dissolved in dry THF $(0.3 \mathrm{~mL})$ and $\operatorname{PBr}_{3}(8.1 \mathrm{mg}$, $0.029 \mathrm{mmol}, 0.4$ equiv) was added at $0{ }^{\circ} \mathrm{C}$. The solution was stirred for $45 \mathrm{~min}$ at room temperature. The reaction mixture was hydrolyzed by addition of ice cold water and extracted three times with pentane. The combined organic layers were dried over $\mathrm{MgSO}_{4}$ and the solvent was removed under reduced pressure. The crude product was used for phosphorylation.

In a second flask, to a solution of $\left(n-\mathrm{Bu}_{4}\right)_{3} \mathrm{HP}_{2} \mathrm{O}_{7}(97 \mathrm{mg}$, $0.11 \mathrm{mmol}, 1.5$ equiv) in dry $\mathrm{CH}_{3} \mathrm{CN}(1.0 \mathrm{~mL})$ the crude product of the allyl bromide (1.0 equiv) was added and the reaction mixture was stirred for $2 \mathrm{~h}$ at room temperature and then concentrated under reduced pressure. The colorless oil was loaded onto an ion exchange column (DOWEX 50W-X8, $\mathrm{NH}_{4}{ }^{+}$ form). Elution of the product was performed by addition of two column volumes of ion exchange buffer $\left(0.03 \mathrm{M} \mathrm{NH}_{4} \mathrm{HCO}_{3}\right.$ in $\left.2 \% \mathrm{iPrOH} / \mathrm{H}_{2} \mathrm{O}\right)$. Freeze drying yielded the product as a white solid (14.1 mg, $0.04 \mathrm{mmol}, 55 \%)$.

${ }^{1} \mathrm{H}$ NMR $\left(500 \mathrm{MHz}, \mathrm{H}_{2} \mathrm{O}\right) \delta 5.37\left(\mathrm{dt},{ }^{1} J_{(\mathrm{C}, \mathrm{H})}=156.7 \mathrm{~Hz}\right.$, $\left.{ }^{3} J_{(\mathrm{H}, \mathrm{H})}=6.9 \mathrm{~Hz}, 1 \mathrm{H}, \mathrm{CH}\right), 5.16-5.11(\mathrm{~m}, 1 \mathrm{H}, 1 \times \mathrm{CH})$, 4.44-4.38 (m, 2H, $\left.1 \times \mathrm{CH}_{2}\right), 2.12-2.06\left(\mathrm{~m}, 2 \mathrm{H}, 1 \times \mathrm{CH}_{2}\right)$, 2.06-2.00(m, $\left.2 \mathrm{H}, 1 \times \mathrm{CH}_{2}\right), 1.65\left(\mathrm{~d},{ }^{3} J_{(\mathrm{C}, \mathrm{H})}=5.2 \mathrm{~Hz}, 3 \mathrm{H}, 1 \times\right.$ $\left.\mathrm{CH}_{3}\right), 1.62\left(\mathrm{~s}, 3 \mathrm{H}, 1 \times \mathrm{CH}_{3}\right), 1.56\left(\mathrm{~s}, 3 \mathrm{H}, 1 \times \mathrm{CH}_{3}\right) \mathrm{ppm} ;{ }^{13} \mathrm{C}$ NMR $\left(125 \mathrm{MHz}, \mathrm{H}_{2} \mathrm{O}\right) \delta 141.9\left(\mathrm{~d},{ }^{1} J_{(\mathrm{C}, \mathrm{C})}=72.7 \mathrm{~Hz}, 1 \times \mathrm{C}_{\mathrm{q}}\right)$, $133.7\left(1 \times \mathrm{C}_{\mathrm{q}}\right), 124.1(1 \times \mathrm{CH}), 119.6\left(\mathrm{~d},{ }^{3} J_{(\mathrm{P}, \mathrm{C})}=8.2 \mathrm{~Hz}, 1 \times\right.$ $\left.{ }^{13} \mathrm{CH}\right), 38.8\left(\mathrm{~d},{ }^{2} J_{(\mathrm{C}, \mathrm{C})}=2.7 \mathrm{~Hz}, 1 \times \mathrm{CH}_{2}\right), 25.6\left(\mathrm{~d},{ }^{3} J_{(\mathrm{C}, \mathrm{C})}=\right.$ $\left.2.9 \mathrm{~Hz}, 1 \times \mathrm{CH}_{2}\right), 24.8\left(1 \times \mathrm{CH}_{3}\right), 16.9\left(1 \times \mathrm{CH}_{3}\right), 15.6(\mathrm{~d}$, $\left.{ }^{2} J_{(\mathrm{C}, \mathrm{C})}=1.2 \mathrm{~Hz}, 1 \times \mathrm{CH}_{3}\right) \mathrm{ppm} ;{ }^{31} \mathrm{P} \mathrm{NMR}\left(202 \mathrm{MHz}, \mathrm{H}_{2} \mathrm{O}\right) \delta$ $-10.0(\mathrm{~m}, 1 \times \mathrm{P}),-10.6(\mathrm{~m}, 1 \times \mathrm{P}) \mathrm{ppm}$. 


\section{Supporting Information}

Synthesis schemes, Mosher ester analysis of $(R)$ - and $(S)-\left(1-{ }^{2} \mathrm{H}\right) \mathrm{GPP}$, gas chromatogram of the enzyme product of 1,8-cineol synthase, ${ }^{13} \mathrm{C}$ NMR of the enzyme product from $\left(2-{ }^{13} \mathrm{C}\right) \mathrm{GPP}$ in deuterium oxide buffer, and full NMR data of 1 .

\section{Supporting Information File 1}

Additional material.

[http://www.beilstein-journals.org/bjoc/content/ supplementary/1860-5397-12-225-S1.pdf]

\section{Acknowledgements}

This work was funded by the DFG (DI1536/7-1) and by a Ph.D. scholarship of the Fonds der Chemischen Industrie to JR.

\section{References}

1. Degenhardt, J.; Köllner, T. G.; Gershenzon, J. Phytochemistry 2009, 70, 1621-1637. doi:10.1016/j.phytochem.2009.07.030

2. Citron, C. A.; Gleitzmann, J.; Laurenzano, G.; Pukall, R.; Dickschat, J. S. ChemBioChem 2012, 13, 202-214. doi:10.1002/cbic.201100641

3. Rabe, P.; Citron, C. A.; Dickschat, J. S. ChemBioChem 2013, 14, 2345-2354. doi:10.1002/cbic.201300329

4. Citron, C. A.; Barra, L.; Wink, J.; Dickschat, J. S. Org. Biomol. Chem. 2015, 13, 2673-2683. doi:10.1039/C4ОВ02609H

5. Yamada, Y.; Kuzuyama, T.; Komatsu, M.; Shin-ya, K.; Omura, S.; Cane, D. E.; Ikeda, H. Proc. Natl. Acad. Sci. U. S. A. 2015, 112, 857-862. doi:10.1073/pnas. 1422108112

6. Quin, M. B.; Flynn, C. M.; Schmidt-Dannert, C. Nat. Prod. Rep. 2014, 31, 1449-1473. doi:10.1039/C4NP00075G

7. Chen, X.; Köllner, T. G.; Jia, Q.; Norris, A.; Santhanam, B.; Rabe, P.; Dickschat, J. S.; Shaulsky, G.; Gershenzon, J.; Chen, F. Proc. Natl. Acad. Sci. U. S. A. 2016, 113, 12132-12137. doi:10.1073/pnas.1610379113

8. Starks, C. M.; Back, K.; Chappell, J.; Noel, J. P. Science 1997, 277 , 1815-1820. doi:10.1126/science.277.5333.1815

9. Baer, P.; Rabe, P.; Fischer, K.; Citron, C. A.; Klapschinski, T. A.; Groll, M.; Dickschat, J. S. Angew. Chem., Int. Ed. 2014, 53, 7652-7656. doi:10.1002/anie.201403648

10. Lesburg, C. A.; Zhai, G.; Cane, D. E.; Christianson, D. W. Science 1997, 277, 1820-1824. doi:10.1126/science.277.5333.1820

11. Klapschinski, T. A.; Rabe, P.; Dickschat, J. S. Angew. Chem., Int. Ed. 2016, 55, 10141-10144. doi:10.1002/anie.201605425

12. Bogazkaya, A. M.; von Bühler, C. J.; Kriening, S.; Busch, A.; Seifert, A.; Pleiss, J.; Laschat, S.; Urlacher, V. B. Beilstein J. Org. Chem. 2014, 10, 1347-1353. doi:10.3762/bjoc.10.137

13. Huber, T.; Weisheit, L.; Magauer, T. Beilstein J. Org. Chem. 2015, 11, 2521-2539. doi:10.3762/bjoc.11.273

14. Croteau, R.; Alonso, W. R.; Koepp, A. E.; Johnson, M. A. Arch. Biochem. Biophys. 1994, 309, 184-192. doi:10.1006/abbi.1994.1101

15. Rinkel, J.; Dickschat, J. S. Beilstein J. Org. Chem. 2015, 11 , 2493-2508. doi:10.3762/bjoc.11.271
16. Meguro, A.; Motoyoshi, Y.; Teramoto, K.; Ueda, S.; Totsuka, Y.; Ando, Y.; Tomita, T.; Kim, S.-Y.; Kimura, T.; Igarashi, M.; Sawa, R.; Shinada, T.; Nishiyama, M.; Kuzuyama, T. Angew. Chem., Int. Ed. 2015, 54, 4353-4356. doi:10.1002/anie.201411923

17. Matsuda, Y.; Mitsuhashi, T.; Lee, S.; Hoshino, N.; Mori, T.; Okada, M.; Zhang, H.; Hayashi, F.; Fujita, M.; Abe, I. Angew. Chem., Int. Ed. 2016, 55, 5785-5788. doi:10.1002/anie.201601448

18. Okada, M.; Matsuda, Y.; Mitsuhashi, T.; Hoshino, S.; Mori, T.; Nakagawa, K.; Quan, Z.; Qin, B.; Zhang, H.; Hayashi, F.; Kawaide, H.; Abe, I. J. Am. Chem. Soc. 2016, 138, 10011-10018. doi:10.1021/jacs.6b05799

19. Ye, Y.; Minami, A.; Mandi, A.; Liu, C.; Taniguchi, T.; Kuzuyama, T.; Monde, K.; Gomi, K.; Oikawa, H. J. Am. Chem. Soc. 2015, 137, 11846-11853. doi:10.1021/jacs.5b08319

20. Burkhardt, I.; Siemon, T.; Henrot, M.; Studt, L.; Rösler, S.; Tudzynski, B.; Christmann, M.; Dickschat, J. S. Angew. Chem., Int. Ed. 2016, 55, 8748-8751. doi:10.1002/anie.201603782

21. Rabe, P.; Janusko, A.; Goldfuss, B.; Dickschat, J. S. ChemBioChem 2016, 17, 146-149. doi:10.1002/cbic.201500543

22. Rabe, P.; Rinkel, J.; Klapschinski, T. A.; Barra, L.; Dickschat, J. S. Org. Biomol. Chem. 2016, 14, 158-164. doi:10.1039/C5OB01998B

23. Rabe, P.; Pahirulzaman, K. A. K.; Dickschat, J. S. Angew. Chem., Int. Ed. 2015, 54, 6041-6045. doi:10.1002/anie.201501119

24. Rabe, P.; Schmitz, T.; Dickschat, J. S. Beilstein J. Org. Chem. 2016, 12, 1839-1850. doi:10.3762/bjoc.12.173

25. Dickschat, J. S. Nat. Prod. Rep. 2011, 28, 1917-1936. doi:10.1039/c1np00063b

26. Wise, M. L.; Savage, T. J.; Katahira, E.; Croteau, R. J. Biol. Chem. 1998, 273, 14891-14899. doi:10.1074/jbc.273.24.14891

27. Wise, M. L.; Urbansky, M.; Helms, G. L.; Coates, R. M.; Croteau, R. J. Am. Chem. Soc. 2002, 124, 8546-8547. doi:10.1021/ja0265714

28. Nakano, C.; Kim, H.-K.; Ohnishi, Y. ChemBioChem 2011, 12, 1988-1991. doi:10.1002/cbic.201100330

29. Edelstein, R. L.; Weller, V. A.; Distefano, M. D.; Tung, J. S. J. Org. Chem. 1998, 63, 5298-5299. doi:10.1021/jo980304s

30. Thulasiram, H. V.; Phan, R. M.; Rivera, S. B.; Poulter, C. D. J. Org. Chem. 2006, 71, 1739-1741. doi:10.1021/jo052384n

31. Keller, R. K.; Thompson, R. J. Chromatogr. A 1993, 645, 161-167. doi:10.1016/0021-9673(93)80630-Q

32. Dickschat, J. S.; Pahirulzaman, K. A. K.; Rabe, P.; Klapschinski, T. A. ChemBioChem 2014, 15, 810-814. doi:10.1002/cbic.201300763

33. Oldfield, E.; Lin, F.-Y. Angew. Chem., Int. Ed. 2012, 51, 1124-1137. doi:10.1002/anie.201103110

34. Whittington, D. A.; Wise, M. L.; Urbansky, M.; Coates, R. M.; Croteau, R. B.; Christianson, D. W. Proc. Natl. Acad. Sci. U. S. A. 2002, 99, 15375-15380. doi:10.1073/pnas.232591099

35. Hyatt, D. C.; Youn, B.; Zhao, Y.; Santhamma, B.; Coates, R. M.; Croteau, R. B.; Kang, C. Proc. Natl. Acad. Sci. U. S. A. 2007, 104, 5360-5365. doi:10.1073/pnas.0700915104

36. Baer, P.; Rabe, P.; Citron, C. A.; de Oliveira Mann, C. C.; Kaufmann, N.; Groll, M.; Dickschat, J. S. ChemBioChem 2014, 15, 213-216. doi:10.1002/cbic.201300708

37. Ding, L.; Goerls, H.; Dornblut, K.; Lin, W.; Maier, A.; Fiebig, H.-H.; Hertweck, C. J. Nat. Prod. 2015, 78, 2963-2967. doi:10.1021/acs.jnatprod.5b00674

38. Dickschat, J. S. Nat. Prod. Rep. 2016, 33, 87-110. doi:10.1039/C5NP00102A

39. Gietz, R. D.; Schiestl, R. H. Nat. Protoc. 2007, 2, 31-34. doi:10.1038/nprot.2007.13 
40. Fulmer, G. R.; Miller, A. J. M.; Sherden, N. H.; Gottlieb, H. E.; Nudelman, A.; Stoltz, B. M.; Bercaw, J. E.; Goldberg, K. I.

Organometallics 2010, 29, 2176-2179. doi:10.1021/om100106e

41. Rabe, P.; Barra, L.; Rinkel, J.; Riclea, R.; Citron, C. A.;

Klapschinski, T. A.; Janusko, A.; Dickschat, J. S.

Angew. Chem., Int. Ed. 2015, 54, 13448-13451.

doi:10.1002/anie.201507615

\section{License and Terms}

This is an Open Access article under the terms of the Creative Commons Attribution License

(http://creativecommons.org/licenses/by/4.0), which permits unrestricted use, distribution, and reproduction in any medium, provided the original work is properly cited.

The license is subject to the Beilstein Journal of Organic Chemistry terms and conditions:

(http://www.beilstein-journals.org/bjoc)

The definitive version of this article is the electronic one which can be found at: $\underline{\text { doi:10.3762/bjoc. } 12.225}$ 